\title{
Особенности формирования композиционных структур и локальные эффекты при электроискровом спекании
}

\section{Formation features of composite structures and local effects in spark plasma sintering}

А. В. Дудина', 2, 3, Т. М. Видюк ${ }^{2,4}$, В. И. Квашнин ${ }^{1,3}$,

А. А. Штерцер ${ }^{1}$, А. Г. Анисимов ${ }^{1}$, В. И. Мали ${ }^{1}$, М. А. Есиков ${ }^{1,3}$, А. В. Ухина' ${ }^{2}$ М. А. Корчагин ${ }^{2}$, Б. Б. Бохонов ${ }^{2}$, М. А. Леган ${ }^{1,3}$

1 - Институт гидродинамики им. М.А. Лаврентьева СО РАН, Новосибирск, Россия

2 - Институт химии твердого тела и механохимии СО РАН, Россия

${ }^{3}$ - Новосибирский государственный технический университет, Россия

${ }^{4}$ - Институт теоретической и прикладной механики им. С. А. Христиановича СО РАН, Новосибирск, Россия
D. V. Dudina, 2, 3, T. M. Vidyuk ${ }^{2,4}$, V. I. Kvashnin 1,3,

A. A. Shtertser' ${ }^{1}$ A. G. Anisimov' ${ }^{1}$, V. I. Mali' ${ }^{1}$, M. A. Esikov ${ }^{1,3}$, A. V. Ukhina', M. A. Korchagin'2, B. B. Bokhonov', M. A. Legan ${ }^{1,3}$

1 - Lavrentyev Institute of Hydrodynamics SB RAS, Novosibirsk, Russia

2 - Institute of Solid State Chemistry and Mechanochemistry SB RAS, Novosibirsk, Russia

${ }^{3}$ - Novosibirsk State Technical University, Russia

${ }^{4}$ - Khristianovich Institute of Theoretical and Applied Mechanics SB RAS, Novosibirsk, Russia

поступила в редакцию 12.10 2020, принята к печати 21.10.2020

\section{Абстракт}

В последние годы в материаловедческом сообществе наблюдается значительный интерес к механизмам и технологическим возможностям метода электроискрового спекания (ЭИС). Сущность метода заключается в спекании порошка при приложении одноосного давления и пропускании импульсов электрического тока низкого напряжения через проводящую оснастку, в которой находится образец. В случае порошков электропроводящих материалов электрический ток проходит и через спекаемый образец. При пропускании импульсного электрического тока через порошковый образец могут создаваться условия для протекания физико-химических процессов локального характера; изучение этих процессов помогает глубже понять механизмы формирования и синтеза материалов при ЭИС. В данной статье на примерах результатов, полученных авторами, рассматриваются особенности формирования композиционных структур при ЭИС и эффекты локального характера, возникающие в ходе процесса. Рассматриваются новые приложения метода: проведение химико-термической обработки для получения композиционных порошковых материалов и осуществление соединения макрообъектов посредством пропускания электрического тока через границу раздела.

\begin{abstract}
In recent years, mechanisms and technological possibilities of Spark Plasma Sintering (SPS) have attracted a lot of attention of the materials science community. SPS is sintering of powders under an applied uniaxial pressure by passing pulses of electric current at a low voltage through the tooling made of an electrically conductive material, into which the sample is loaded. In the case of sintering of conductive materials, the electric passes through the sample as well. When pulses of electric current are passing through a powder sample, conditions are created for physical and chemical processes of local character. Investigating these processes helps developing a deeper understanding of the mechanisms of the materials formation and synthesis during SPS. In the present article, based on examples elaborated by the authors, the features of the formation of composite structures and local effects during SPS are discussed. New applications of SPS are outlined: chemical and thermal treatment to produce powders of composite structure and joining of macro-objects by passing electric current through the interface.
\end{abstract}

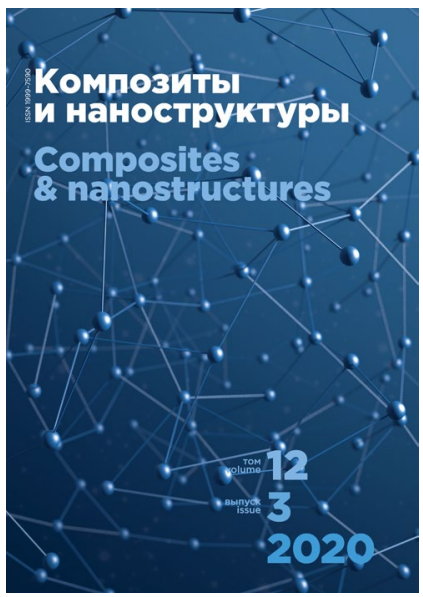

